\title{
Zastosowanie koncepcji Smart City na terenie Łodzi
}

http://dx.doi.org/10.18778/8142-085-3.17

Patrycja Kietbaska, Dominik Wronkowski

Studencki Koło Naukowe Logistyki i Innowacji LOGIN Wydział Ekonomiczno-Socjologiczny, Uniwersytet Łódzki

\section{Wstęp}

Jednym z największych wyzwań współczesnej logistyki jest sprawne zarządzanie transportem ludzi i towarów na obszarach zurbanizowanych. Korki w godzinach szczytu, zły stan infrastruktury i słaby przepływ informacji zmuszają miasta do poszukiwania systemów mogących poprawić funkcjonowanie aglomeracji w takich sytuacjach. Wdrożenie elementów systemu Smart City pozwala w znacznym stopniu zniwelować problemy, z którymi borykają się duże ośrodki miejskie.

\section{Smart City w obszarze transportu i komunikacji miejskiej}

Koncepcja Smart City znajduje zastosowanie w kilku obszarach, takich jak: energetyka, budownictwo, rekreacja oraz transport i komunikacja.

W obszarze transportu i komunikacji miejskiej skupia się na jak najsprawniejszym przemieszczaniu się ludzi i towarów. Głównym problemem w tym obszarze jest tzw. „błędne koło”, czyli wzrost liczby uczestników ruchu, przybywanie pojazdów indywidualnych powodujące spadek liczby pojazdów komunikacji zbiorowej (Wyszomirski, 2002: 24). Rozwiązaniem tego problemu mogą być inteligentne czujniki natężenia ruchu, dające dostęp do sterowania sygnalizacją świetlną, powiększenie infrastruktury transportowej, wybór idealnych lokalizacji na mieszkania, hotele, miejsca pracy, szkoły, centra handlowe, centra logistyczne itp. (Wesołowski, 2008). Społeczeństwo korzysta z wielu osiągnięć cywilizacyjnych 
ludzkości, wiąże się to jednak z zanieczyszczaniem powietrza. Zmniejszeniu skali emisji zanieczyszczeń mogą przysłużyć się innowacyjne urządzenia infrastruktury transportowej, informatycznej, technicznej i sanitarnej. Ważne jest również inteligentne wykrywanie zanieczyszczeń w środowisku i ustalanie miejsce ich wytwarzania. Technologia ICT wspomaga ochronę środowiska np. dzięki tworzeniu baz danych, które informują o najbardziej zanieczyszczonych obszarach w mieście (Stawasz, Sikora-Fernandez, 2015: 52).

W obszarze transportu i komunikacji rozwiązania można podzielić na infrastrukturalne i organizacyjne. Rozwiązania infrastrukturalne polegają na rozbudowie oraz unowocześnianiu infrastruktury już istniejącej oraz uwzględnianiu tej, która jest dopiero w planach (Wesołowski, 2008: 20). Rozwiązania organizacyjne to np. utworzenie węzłów przesiadkowych wraz z systemem multimodalnym wiążącym się z systemami Park \& Ride i Bike \& Ride. Systemy te prowadzą do utworzenia parkingów, na których podróżni mogą zostawić swój pojazd i podróżować dalej komunikacją miejską. Przykładem takiego rozwiązania są miejskie rowery publiczne, których stacje najczęściej zlokalizowane są w obrębach przystanków. W Polsce takie rozwiązania można zobaczyć np. w Warszawie, Poznaniu i Gdańsku. Z myślą o komforcie poruszania się po drogach wyznaczono BUS-pasy oraz ścieżki rowerowe. Kolejnym rozwiązaniem jest zsynchronizowanie rozkładów jazdy dworców PKP i PKS z komunikacją miejską. Biletomat w autobusie i tramwaju to innowacyjny sposób na zakup biletu. W takim biletomacie jest możliwość zakupu biletów z pełnej oferty. Można też kupić bilet elektroniczny przez smartfona. Dla pieszych rozwiązaniem smart będą bezkolizyjne przejścia przez jezdnię z przedłużonym czasem faz sygnalizacji. Promowanie roweru miejskiego mieści się również w rozwiązaniach Smart City (Stawasz, Sikora-Fernandez, 2015: 50-51).

Zgodnie z koncepcją Smart City w Polsce transport i komunikacja to najbardziej rozbudowany i najważniejszy obszar. Ruch miejski uzależniony jest od aktywności mieszkańców. Im większe jego natężenie, tym większa konieczność wprowadzenia usprawnień w ruchu transportowym.

\section{Zastosowanie koncepcji Smart City na przykładzie Łodzi}

Wdrożenie Inteligentnych Systemów Transportowych na terenie Łodzi miało na celu optymalizację czasu przejazdu komunikacją miejską, szybkie i efektywne przesyłanie informacji o ruchu pojazdów komunikacji miejskiej, ulepszenie jakości komunikacji miejskiej i poprawę jakości życia w mieście. Rozwiązania 
wprowadzone $\mathrm{w}$ Łodzi to modernizacja oraz tworzenie nowych sygnalizacji świetlnych połączonych z systemami, które uwzględniają większą liczbę skrzyżowań w Łodzi.

\subsection{System monitorowania}

System monitorowania miasta służy kontroli ruchu miejskiego na drogach. Pracownicy centrum operacyjnego będą mieć za zadanie kontrolować stan dróg i ruch na drogach, ale także czuwać nad poprawnym działaniem systemu. Ilustracja 1 przedstawia przykładowe centrum operacyjne, gdzie wyraźnie widać, jak wygląda praca w takim miejscu ${ }^{1}$.

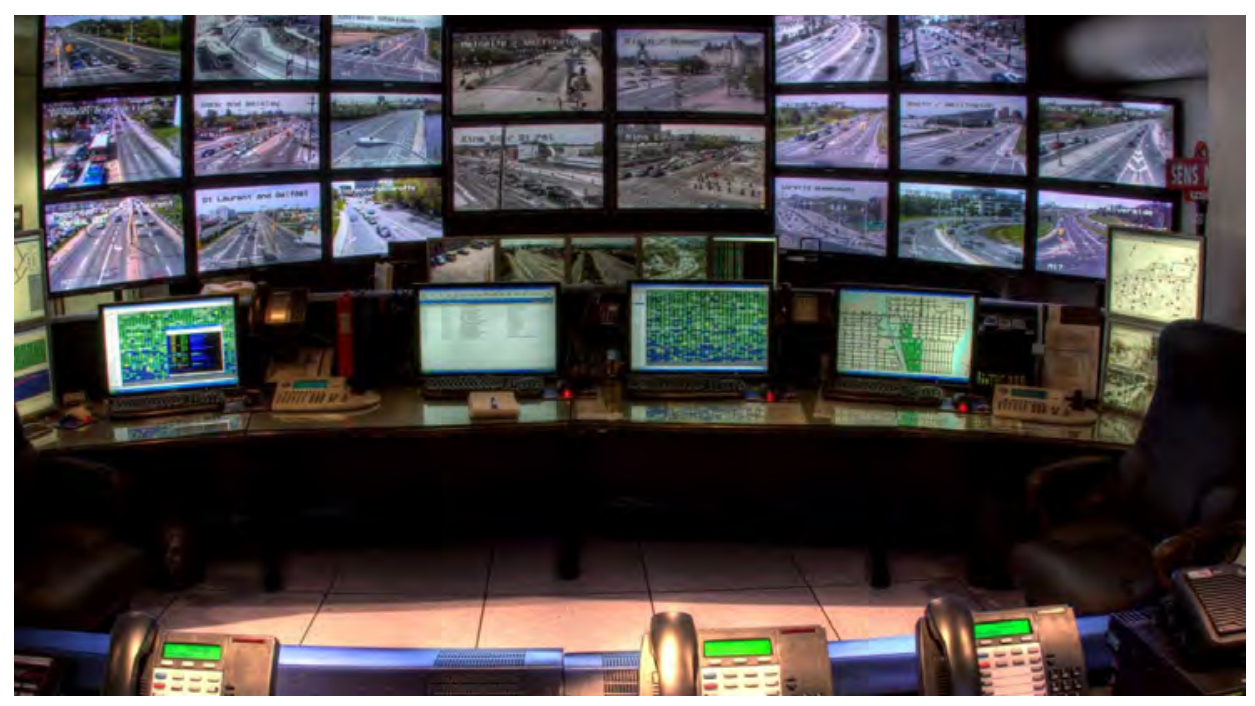

Ilustracja 1. Przykład centrum operacyjnego

Źródło: Large-scale ITS system planned for Łódź, http://www.eltis.org/discover/news/ large-scale-its-system-planned-lodz-poland [dostęp 15.05.2017].

\subsection{Trasa $W-Z$}

Łódź posiada największe Inteligentne Systemy Transportowe w Polsce. W Łodzi powstała trasa W-Z, łączy ona Retkinię (zachodnia część Łodzi) z Janowem (wschodnia część Łodzi). Trasę udostępniono dla użytkowników 31 października 2015 r. (zob. ilustr. 2).

1 http://www.its.lodz.pl/\# [dostęp 15.05.2017]. 


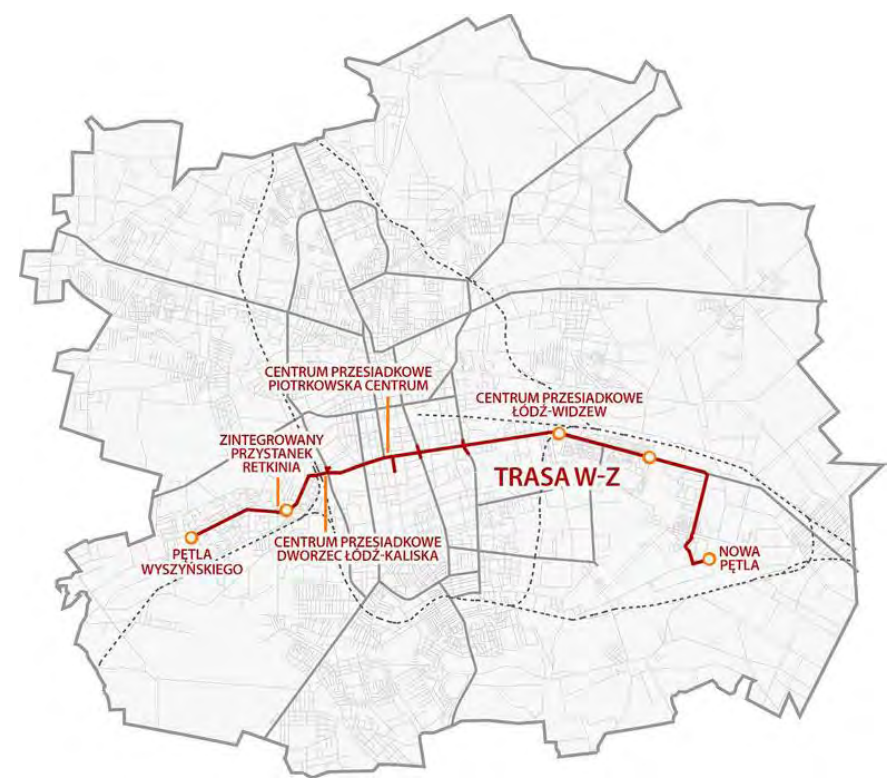

Ilustracja 2. Mapa trasy W-Z

Źródło: http://www.expressilustrowany.pl/artykul/zdjecia/889424,tak-bedzie-wygladala-trasawz-mapa-wizualizacja-film,1920268,id,t,zid.html [dostęp 25.05.2017].

W wyniku budowy trasy W-Z powstał węzeł przesiadkowy Piotrkowska Centrum, z którego można dojechać w każdą część miasta.

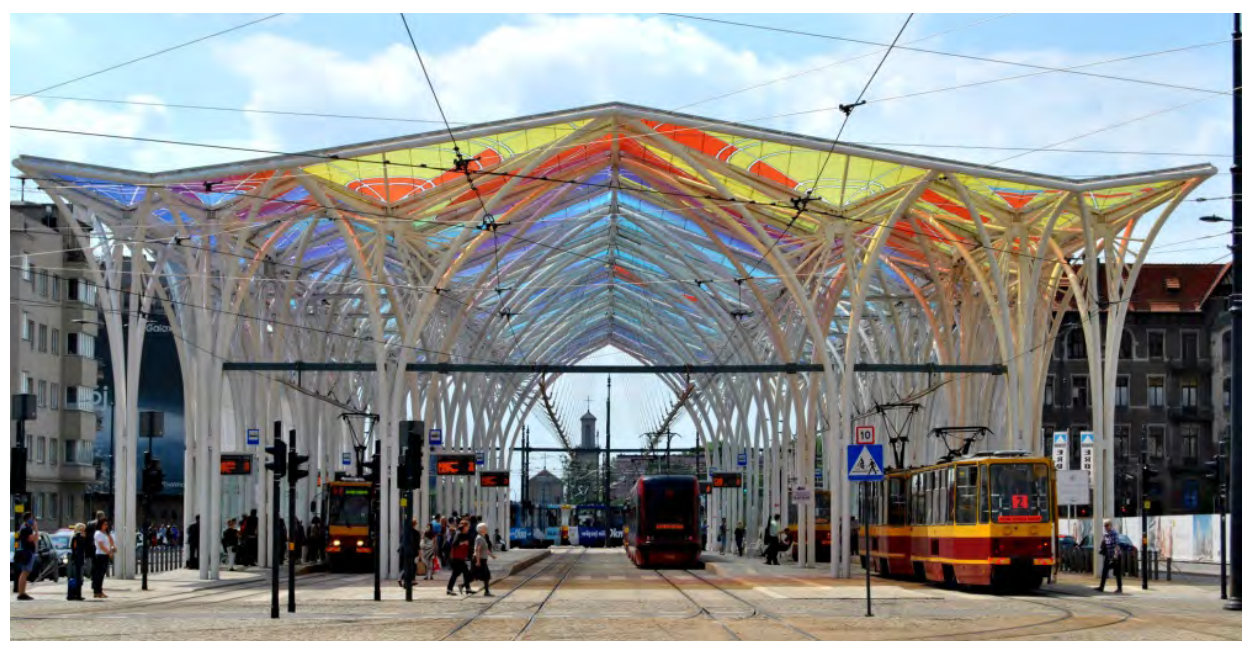

Ilustracja 3. Węzet przesiadkowy Piotrkowska Centrum

Źródło: fotografia w posiadaniu autora. 
Powstały tunele ograniczające ruch na drodze przy torach tramwajowych, co ma na celu optymalizować ruch i zapobiec korkowaniu się dróg. Wdrożone również zostały systemy informacyjne dla kierowców oraz pasażerów. Zastosowano tablice zmiennej treści, dzięki którym możliwe jest ustalenie aktualnej sytuacji na drodze. Stanowi to pomoc w planowaniu kolejnego docinka trasy, tak by ograniczyć czas przejazdu. W Łodzi powstało aż dziewięć takich znaków (Barwiński, Kotas, 2016: 146) (zob. ilustr. 4).


Ilustracja 4. Tablice zmiennej treści w Centrum Łodzi Źródto: fotografia w posiadaniu autora.

\subsection{Tablice informacyjne}

Na przystankach tramwajowych oraz autobusowych powstały również tablice informacyjne $\mathrm{z}$ bieżącymi informacjami na temat przyjazdu danego środka komunikacji, zmian tras pojazdów bądź zakłóceń na drodze. Tablice te działają dzięki usytuowanym w autobusach i tramwajach nadajnikom GPS. Informacja najpierw wysyłana jest do sieci, a następnie dostarczana do centrum dynamicznej informacji pasażerskiej, które w efekcie końcowym umieszcza wiadomość na temat pojazdów na tablicy².

2 https://www.wasko.pl/voyager-sdip/ [dostęp 15.05.2017]. 


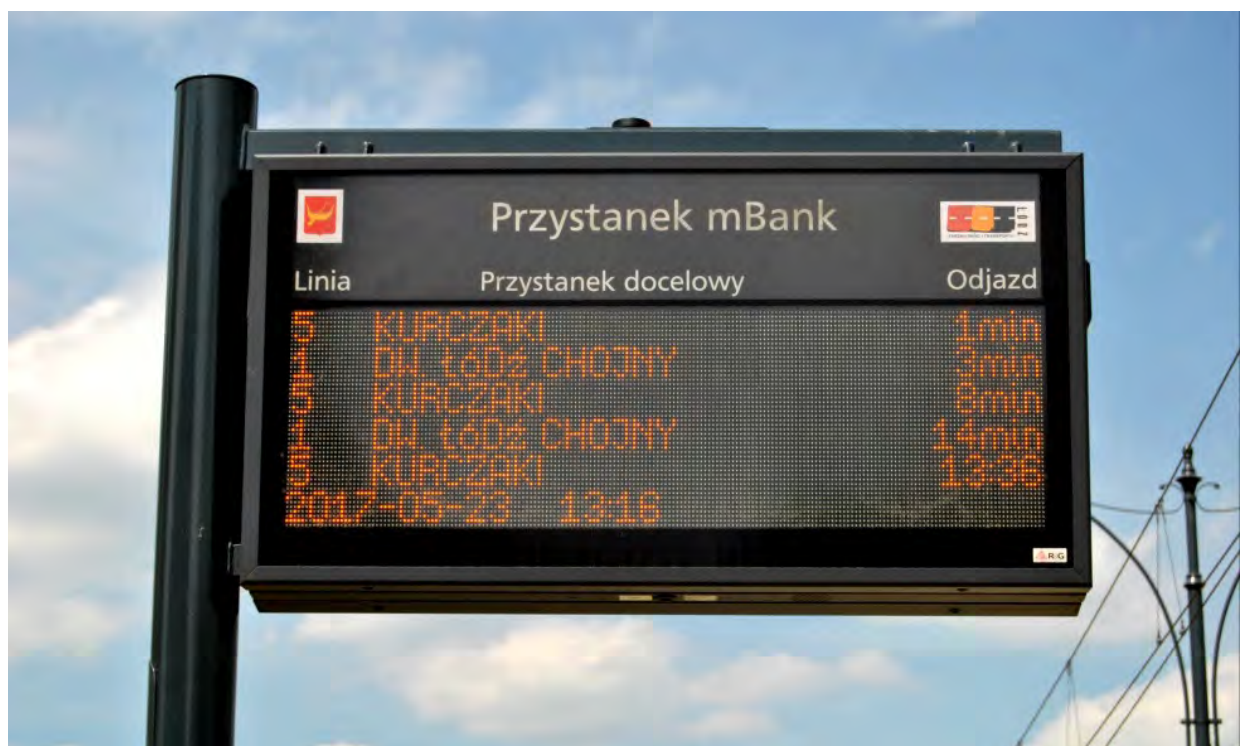

Ilustracja 5. Tablica informacyjna w Centrum Łodzi

Źródło: fotografia w posiadaniu autora.

\subsection{Monitoring}

W Łodzi zainstalowanych jest ok. 350 kamer w 129 miejscach. Dzięki systemowi monitoringu od 2016 do roku 2017 zarejestrowano 3 tysiące niebezpiecznych sytuacji. Zainstalowano również ok. 50 kamer CCTV, czyli takich, które skupiają się na ograniczonym obszarze w celu zwiększenia jego bezpieczeństwa ${ }^{3}$.

Kolejnym rozwiązaniem smart jest instalowanie systemów ANPR. Technologię tę wykorzystuje głównie policja, ale przydaje się ona również na parkingach. Jest to system rozpoznawania tablic rejestracyjnych. Polega na odczytywaniu i rozpoznawaniu znaków ze zdjęcia. Na działanie tej technologii składają się kamery będące w stanie rozpoznać tablicę oraz programy potrafiące odczytać dane z tablicy. Korzyścią z zamieszczenia takiego systemu jest oszczędność wynikająca z braku potrzeby zatrudnienia osoby, która miałaby zająć się tym systemem. System działa automatycznie. W Łodzi zamieszczono ok. 226 tego typu kamer"

3 P. Grenda, Co to jest system CCTV?, http://camsat.com.pl/s/wsparcie/artykuly/co-to-jestsystem-cctv [dostęp 15.05.2017].

4 Komisja Transportu Związku Miast Polskich, ITS - Inteligentne Systemy Transportowe, http://www.zmp.poznan.pl/uploads/attachment/file/1138/Za__cznik_3_ITS.pdf [dostęp 15.05.2017]. 


\subsection{Rower Miejski}

Bardzo ważnym rozwiązaniem jest Łódzki Rower Publiczny. Możliwość skorzystania $\mathrm{z}$ roweru miejskiego to świetna alternatywa dla aktywnych ludzi, ale także dla reszty społeczeństwa. Rower publiczny to środek transportu, dzięki któremu każdy użytkownik zyskuje gwarancję szybszego i sprawniejszego przemieszczania się po centrum Łodzi. Łodzianie mają do dyspozycji 1000 rowerów miejskich oraz 100 stacji. Użytkowanie roweru miejskiego jest bardzo łatwe, wystarczy zarejestrować się na stronie bądź w aplikacji, podejść do terminala i wypożyczyć rower, a po udanej przejażdżce zwrócić rower w jakiejkolwiek stacji na terenie miasta. Początkowo stacje rowerów miejskich utworzono tylko w centrum Łodzi, obecnie Łódzki Rower Publiczny rozszerza zakres stacji na inne dzielnice Łodzi (Witkowska, 2017) (zob. ilustr. 6).

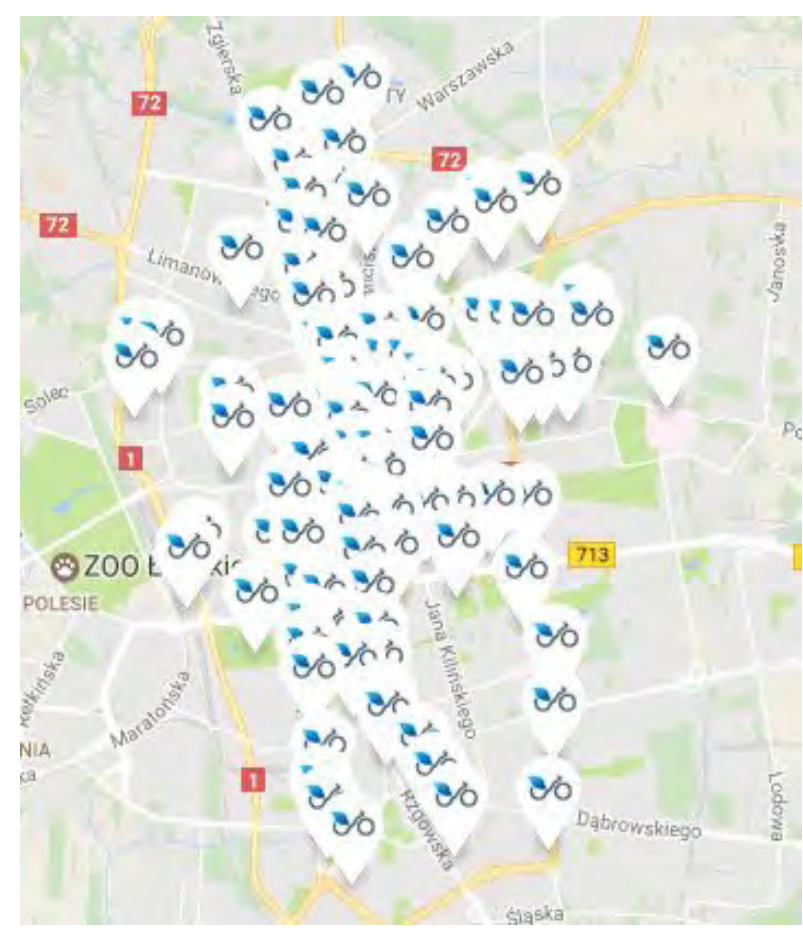

Ilustracja 6. Mapa stacji Roweru Publicznego w Łodzi

Źródło: https://lodzkirowerpubliczny.pl/mapa-stacji/ [dostęp 15.05.2017].

Jak widać, miasto chce się rozwijać $\mathrm{w}$ zgodzie $\mathrm{z}$ ekologią i zdrowym trybem życia, obecnie stacje roweru publicznego można znaleźć na każdym osiedlu. 


\subsection{Dworzec Łódź Fabryczna}

W 2016 r. otwarty został po przebudowie dworzec Łódź Fabryczna. Zbudowano go w samym centrum Łodzi, dzięki komunikacji miejskiej ma doskonałe połączenie $\mathrm{z}$ resztą miasta. Został on odnowiony po raz trzeci. Koszt tej inwestycji był dość wysoki, bo wyniósł aż 1759289451 zł ${ }^{5}$.W dalszym etapie ma dojść do zbudowania tunelu, który będzie łączył Łódź Fabryczną z Łodzią Kaliską. Prace nad budową rozpoczną się w roku 2018 i zakończyć się mają w 2023 r. W trakcie budowy tunelu ma powstać przystanek Zielona/Centrum. Będzie to oczywiście przystanek dostępny dla pociągów ${ }^{6}$.

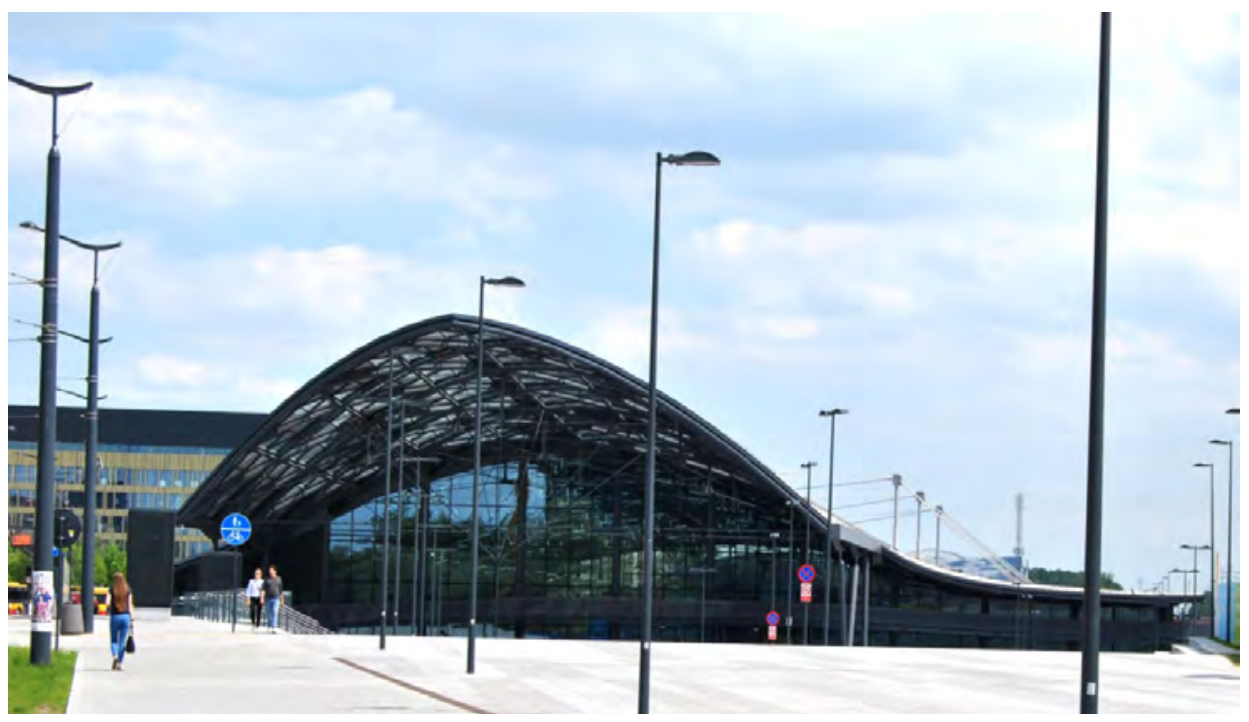

Ilustracja 7. Dworzec Łódź Fabryczna

Źródto: fotografia w posiadaniu autora.

\section{Podsumowanie}

Smart City to koncepcja, która wspiera rozwój miast na całym świecie. Podstawowe jej zadanie polega na wdrażaniu działań mających na celu rozwój miasta przy zachowaniu ekologicznych rozwiązań. Inteligentne miasta to takie, w których roz-

5 O inwestycji, http://www.nlf-b2.pl/o-inwestycji [dostęp 16.05.2017].

6 Tunel kolejowy w Łodzi. Początek budowy w 2018 roku, http://lodz.naszemiasto.pl/artykul/tunelkolejowy-w-lodzi-poczatek-budowy-w-2018-roku,3484912,art,t,id,tm.html [dostęp 25.05.2017]. 
wój zaangażowane są technologie informacyjno-komunikacyjne. Działania tych technologii skutkują poprawą wydajności infrastruktury miejskiej oraz wpływają pozytywnie na zadowolenie mieszkańców. Koncepcja Smart City funkcjonuje głównie w transporcie i komunikacji miejskiej. Mieszkańcy potrzebują stworzenia zorganizowanej przestrzeni przeznaczonej na ruch miejski biorącej pod uwagę ich bezpieczeństwo. Wprowadzenie koncepcji Smart City jest znaczącym elementem poprawy funkcjonowania miast, ponieważ zgodnie z założeniami tej koncepcji wytwarza się mniej zanieczyszczeń, życie w mieście staje się wygodniejsze i łatwiejsze, co udowadniają takie rozwiązania jak monitorowanie miasta, bezkolizyjne przejścia dla pieszych i elektroniczne tablice informacyjne.

\section{Bibliografia}

Barwiński S., Kotas P., (2016), Inteligentne Systemy Transportowe jako narzędzie rozwiq̨zywania problemów komunikacyjnych miast na przykładzie Łodzi, [w:] W. Grzegorczyk (red.), Wybrane problemy zarządzania i finansów. Studia przypadków, Wydawnictwo Uniwersytetu Łódzkiego, Łódź.

Stawasz D., Sikora-Fernandez D., (2015), Zarzq̨dzanie w polskich miastach zgodnie z koncepcja Smart City, Wydawnictwo Placet, Warszawa.

Wesołowski J., (2008), Miasto w ruchu. Dobre praktyki w organizowaniu transportu miejskiego, Instytut Spraw Obywatelskich, Łódź, http://miastowruchu.pl/doc/miasto_w_ruchu_ebook. pdf [dostęp 14.05.2017].

Witkowska M., Łódzki Rower Publiczny się rozrasta. Powstana 103 nowe stacje, http://www. dzienniklodzki.pl/wiadomosci/lodz/a/lodzki-rower-publiczny-sie-rozrasta-powstana-103nowe-stacje-mapa,11688914/ [dostęp 15.05.2017].

Wyszomirski O., (2002), Gospodarowanie w komunikacji miejskiej, Uniwersytet Gdański, Gdańsk.

\section{Źródta internetowe}

http://camsat.com.pl/s/wsparcie/artykuly/co-to-jest-system-cctv [dostęp 15.05.2017].

http://www.zmp.poznan.pl/uploads/attachment/file/1138/Za__cznik_3_ITS.pdf [dostęp 15.05.2017].

http://www.dzienniklodzki.pl/wiadomosci/lodz/a/lodzki-rower-publiczny-sie-rozrastapowstana-103-nowe-stacje-mapa,11688914/ [dostęp 15.05.2017].

http://lodz.naszemiasto.pl/artykul/tunel-kolejowy-w-lodzi-poczatek-budowy-w-2018roku,3484912,art,t,id,tm.html [dostęp 25.05.2017].

http://www.its.lodz.pl/\# [dostęp 15.05.2017].

http://www.nlf-b2.pl/o-inwestycji [dostęp 16.05.2017].

https://www.wasko.pl/voyager-sdip/ [dostęp 15.05.2017]. 